\title{
Firm Specific and Macroeconomic Determinants of Capital Structure: Evidence from Fragile Five Countries
}

\author{
Osman SAHIN ${ }^{*}$
}

Received: December 17, 2017 Revised: September 2, 2018 Accepted: September 23, 2018.

\begin{abstract}
This study is based on the non-financial companies within the fragile five countries (Turkey, Brazil, South Africa, India and Indonesia) during the period of 2004-2013. The factors affecting capital structure were assessed along with micro and macro variables for these countries. The micro variables (firm specific) included in the model were the debt taken in the previous year, firm size, growth, industry debt average, and the tangibility and profitability ratio; GDP growth, inflation and exchange rate change were included in the model as macroeconomic variables. Also, the effects of financial crises were analyzed by treating pre- and post-2008 crisis periods separately. Panel data analysis techniques are used to identify the relationships between these determinants and capital structure. The relationship between the real effective exchange rate and the debt ratio was positive in the precrisis five-country model, but it turned negative in the post-crisis model. A statistically significant relationship was discovered between the GDP growth rate and the debt ratio only for Turkey for the full period (2004-2013) and for India for the period between 2006 and 2013. On the other hand, a positive relationship was found between the inflation rate and the debt ratio for the general (2004-2013) and post-crisis models.
\end{abstract}

Keywords: Capital structure, macroeconomic factors, firm specific factors, financial crisis, fragile five countries

JEL Code Classification: C33, E44, G01, G32

UDC: $336.647 / .648$

DOI: https://doi.org/10.17015/ejbe.2018.022.03.

Professor of Finance. Nile University of Nigeria, Abuja, Nigeria. E-mail: sahinosman@hotmail.com 


\section{Introduction}

The Fragile Five reference was first introduced by Morgan Stanley in 2013 for countries which are heavily dependent on foreign capital for financing their current account deficit. Their common features are high current account deficits, high inflation rates, low growth rate performance, high political risk and high unemployment rate.

As noted in the International Monetary Fund's (IMF) October 2015 report, "Global Financial Stability Report: Vulnerabilities, Legacies, and Policy Challenges: Risks Rotating to Emerging Markets," the corporate debt of nonfinancial firms across major emerging market economies rose from about \$4 trillion in 2004 to over \$18 trillion in 2014 (Figure 1A). The report also indicates that the corporate debt-toGDP ratio has grown by 22.68 percent in Turkey, 14.56 percent in Brazil, 13.97 percent in India and 8.8 percent in Indonesia and has declined by 5.59 percent in South Africa.

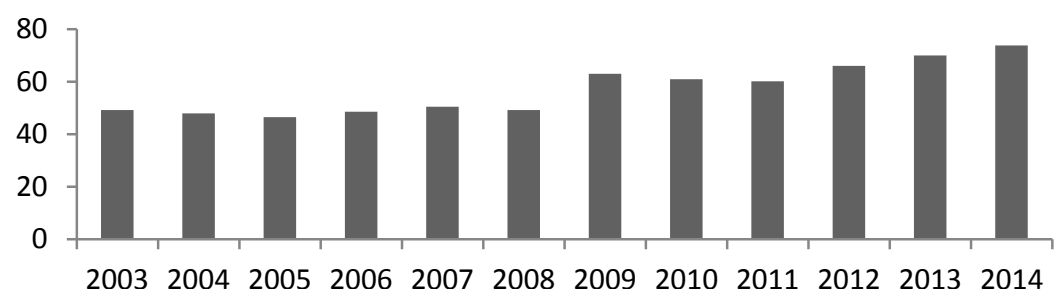

Figure 1A. Total Major EM Corporate Debt (percent of GDP)

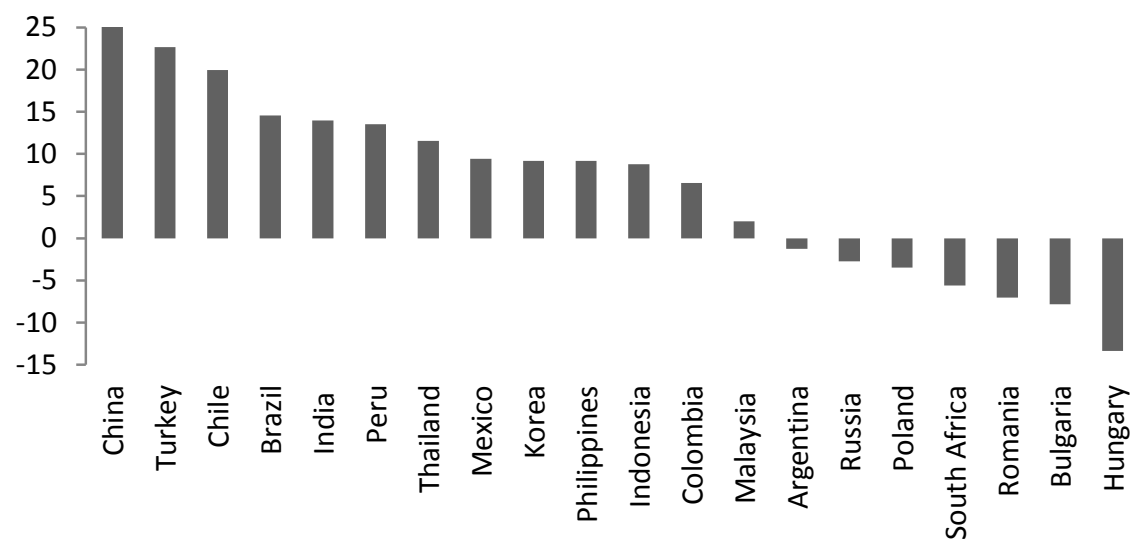

Figure 1B. Change in Corporate Debt: 2007-2014 (in percent of GDP)

Sources: Ayala, Nedeljkovic, and Saborowski (2015); Bank for International Settlements; Dealogic; IMF, International Financial Statistics database; national authorities; and IMF staff calculations.

Note: $\mathrm{EM}=$ emerging market economy; figure depicts major EMs. Debt includes bank credit and bond financing. 
In an effort to get rid of the 2007 crisis, developed countries considerably lowered their interest rates, and some of them-in particular, the United States-sought to provide markets with significant amounts of funds to alleviate market stagnation. Due to market stagnation and low interest rates in developed countries, the funds were channeled to developing countries which promised high returns with high interest rates on investment. This eventually contributed to the abundance of liquidity after the crisis, making it possible for these countries to maintain high growth rates.

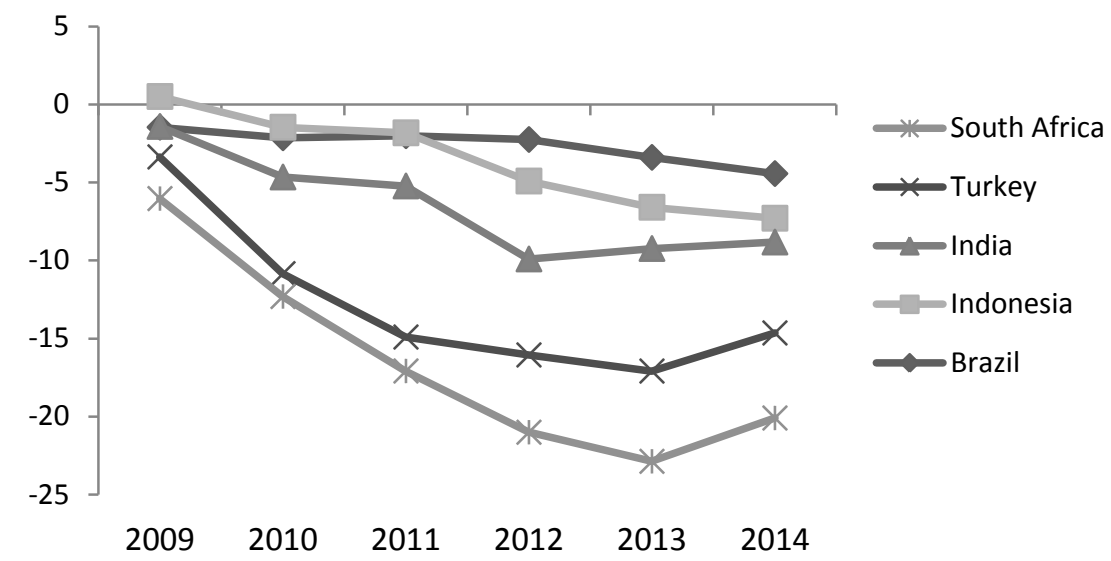

Figure 2. Current Account Balance as \% of GDP for Fragile Five Countries

Source: Worldbank, 2016

The improving economic indicators, however, trigged debates on the need to pump 85 billion dollars into markets on a monthly basis and, eventually, this sum was gradually decreased. This, in turn, resulted in the contraction of liquidity all around the world, particularly in developing countries, and foreign investors started to shy away from them. As the current deficit problem continued to persist, the economies of these countries became more fragile due to the emerging liquidity problem.

The currencies of the developing countries became extremely vulnerable to the developments in global markets, especially to those in the US, and volatility in their markets soared. In an effort to compensate, these countries increased their interest rates, which failed to halt the depreciation of their currencies against the US dollar. This, in turn, resulted in a huge rise in debt in local currencies of the firms that had borrowed in foreign currencies.

As of March 4, 2015, South Africa had the highest growth rate and the lowest inflation and interest rates, but the highest unemployment rate. In India, the growth and inflation rates are, respectively, $1.5 \%$ and $5.11 \%$, but the interest rate is the highest. Indonesia, which relies on its huge supply of natural resources, has the 
same interest rate as Turkey, and it is more successful in keeping the interest rate under check, but has the highest growth rate. Brazil, on the other hand, has the lowest unemployment rates, but suffers from a negative growth rate, high interest and inflation rates. Summing up, all these countries still remain fragile (Makro Analiz, 2015). Due to increasing interdependence in global finance, firms' debt policies have become more and more important. This article aims to identify the macroeconomic and firm-specific variables that determine capital structures of the Fragile Five countries' non-financial companies.

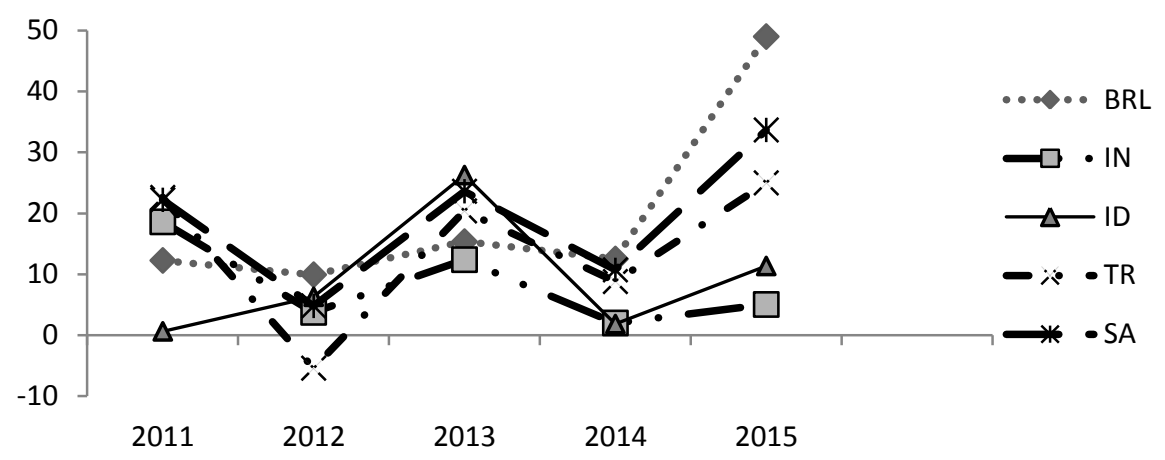

Figure 3. Changes as percentages in FX spot rate (USD) for Fragile Five

\section{Countries}

Source: Thomson Reuters Eikon, 2016

So that it became too important to understand the decision-making process of debt management and/or capital structure fragile five countries. Based on this, in this study, it was tried to see whether firm-specific factors and macroeconomic parameters effect the capital structure decisions of the companies or not and analysed effects (positive or negative) of them. At the same time, it was checked the financial crises effect on these relationships.

Unlike other studies, this article focuses on the effects of the exchange growth rate on the capital structure as well. The exchange growth rate could be integrated into the model thanks to the correlation between this variable and the expected inflation rate being low (0.04).

\section{Literature Review}

Using cost-benefit analysis, companies should develop their own optimal capital structure. For such an analysis, the relationships between capital structure determinants and debt ratio are required. A number of theories have been put forward to relate these variables.

Financial decisions are critical for companies. They can use internal resources, equity or debts to finance their needs. Excessive debt financing has inherent risks 
like default, higher interest cost, and financial distress. Equity financing also has some shortcomings such as opportunity cost of equity, lack of using financial leverage and tax shield advantages.

Modigliani and Miller (1958) put forward what came to be referred to as the MM theory, which maintains that capital structure preferences do not contribute to the firm's value. However, in their 1963 study, they came to acknowledge the leverage effect and tax advantage of borrowing, noting that financing via debts has lower costs than financing via shareholder's equity. So a number of theories were developed on capital structure. Miller (1977) argued that the tax advantage of borrowing would be offset by the income tax to be collected from the dividends that are paid, and Stiglitz (1972), Myers (1984) and Titman (1984) maintained that bankruptcy costs attributable to high borrowing risks would perform the same offsetting function. Ross (1971) asserted that the high level of borrowing by a firm would be a sign of that firm's sound financial structure. Myers and Majluf (1984) theorized on the concept of asymmetrical information resulting from the fact that firms' managers have more knowledge than investors.

Myers (1984) further put forward his pecking order theory, which proposes that firms would tend to proceed first with internal resources and then with debts and eventually with stocks due to the asymmetrical information in the markets. Jensen and Meckling (1976) as well as Myers (1977) discussed the agency problem by investigating the impact of the conflict of benefits between managers and shareholders as well as between shareholders and debtors on capital structure.

According to The Trade-Off Theory, the optimal capital structure is attained in an interval at which there is a trade-off between the benefits of debts and the financial distress of debts and bankruptcy costs (Bradley et al., 1984). Maintaining that it would be beneficial to borrow up to this point and that those firms with strong capital structure, (having more tangible assets and high profitability and therefore a higher leverage ratios), Hovakimian et al. (2001) indicated that highly profitable firms may temporarily move away from the most attractive leverage ratio level, but eventually return to that level. According to this theory, firms should prefer using debt rather than internal resources due to its tax shield and leverage effect. This theory assumes a positive relationship between profitability and the optimal leverage ratio because more profitable firms have lower expected bankruptcy cost and a higher tax advantage. More precisely, they will prefer external finance to internal finance.

In the studies conducted, the positive relationship between the firm value, profitability and debt ratio was regarded as validation of the trade-off theory. Koksal and Orman (2014) concluded that the trade-off theory is more valid in explaining the capital structures of nonfinancial firms in Turkey.

Jensen and Ruback (1983), Jensen (1986, 1988), Pinegar and Willbicht (1989) and Boodho (2009) put forward the idea that using debts would be more beneficial in 
order to minimize agency costs as managers would be motivated to work harder to pay those debts.

On the other hand, investors are not as informed as managers about the firm due to the asymmetrical information problem, a concept introduced by Myers and Majluf (1984), and therefore, firms would issue share certificates below their real values (Frank \& Goyal, 2008) in the pecking order approach. Likewise, as credit institutions are not sufficiently informed about how the firms that borrow from them will use the loans, this risk is reflected in credit costs. Due to increased credit costs, the firms with higher profits and risks will be more eager to receive credits. Therefore, the costs of using external resources are higher than that of using internal ones. All these pricing problems would lead to an adverse selection effect that would result in wrong decisions. Eventually, firms would proceed with financing first with internal resources, then with debts, then with convertible bonds and finally with share certificates issued.

The pecking order theory (financial hierarchy) came into existence because of the asymmetric information problem, which arises because managers have more information about their companies than potential investors. Investors undervalue firms because of this problem; therefore managers will prefer internal financing to external financing. The pecking order theory expects a negative relationship between profitability and leverage ratio because of the fact that, typically, more profitable firms have built up more internal funds.

The studies suggest that for the validity of the pecking order theory, there should be a negative relationship among the firm value, profitability and borrowing (Rajan \& Zingales, 1995; Frank \& Goyal, 2003).

The pecking order theory was found to apply for industrial enterprises in Okuyan and Tasci's (2010) study on Turkey's 1,000 largest industrial enterprises for the period between 1993 and 2007; for export companies in Değirmen and Gündoğdu's (2010) study on Turkish export companies for the period between 1997 and 2008; for sector service firms in Demirhan's (2009) study on services sector companies publicly traded on the Istanbul Stock Exchange for the period between 2003 and 2006; for the companies in Chen and Zhao's (2005) study on US manufacturing enterprises for the period between 1971 and 2001; and in Huang and M. Song's (2006) study on 1,200 Chinese companies for the period between 1994 and 2003.

The trade-off theory maintains that there should be a positive relationship between the debt ratio and the logarithm of the size of assets while the pecking order theory argues that this relationship should be negative. As the default risk is lower for the large firms that resort to diversification, the trade-off theory argues that these firms will look for more borrowing (Frank \& Goyal, 2008).

The trade-off theory expects a negative relationship between the change in the growth of assets and debt utilization while the pecking order theory argues that this relationship should be positive. The trade-off theory purports that debts 
should not be used to finance growth so that financial distress costs do not reduce the value of the firm's assets. The free cash flow problems should diminish and the agency problems stemming from loans should be minimized. The pecking order theory, on the other hand, holds that as internal resources would not be enough to drive growth, those firms must then resort to debts for financing purposes (Frank \& Goyal, 2009).

The pecking order theory expects a negative relationship between tangibility and debt ratio Harris and Raviv (1991) while the trade-off theory argues that this relationship is positive (Stohs \& Mauer, 1996; Frank \& Goyal, 2009).

In addition to the above-mentioned studies on the relationship between the capital structure and firm specific variables, there are studies that focus on the relationship between capital structure and macroeconomic variables. Bastos, Nakamura and Basso (2009), Bokpin (2009), Dincergok and Yalciner (2011) and Camara (2012) maintained that there is a negative relationship between the GDP and GDP growth rate and the capital structure debt ratio, which implies that firms tend to rely on internal resources when their profitability increases; this finding is supportive of the pecking order theory.

Taggart (1985) asserted that when there is a strong relationship between the expected inflation and market interest rates, the expected high inflation rate would result in a higher debt tax shield effect, and as a result, the debt utilization rate will increase, which complies with the expectations of the trade-off theory. Frank and Goyal (2009) maintained that there is a relationship between the inflation rate and market leverage ratio, but there is no relationship between the book value and the calculated debt ratio. They indicated that this relationship was positive in their study on US firms between 1950 and 2003. Likewise, Sett and Sarkhel (2010) and Hanousek and Shamshur (2011) confirmed this positive relationship. Gajurel (2006) asserted that this relationship is negative for the total debt ratio and short-term debt ratio and positive for the long-term debt ratio.

The industry median leverage is generally considered as a measure for determining the target debt structure (Gilson, 1997; Hull, 1999; Hovakimian, Opler \& Titman, 2001; Faccio \& Masulis, 2005; Flannery \& Rangan, 2006). The trade-off theory predicts that higher industry median growth rates will lead to lower debt ratios, while higher industry median debt ratios will result in higher debt ratios (Frank \& Goyal, 2009).

\section{Methodology and Models}

\subsection{Methodology}

This study is based on the non-financial companies within the Fragile Five countries (Turkey, Brazil, South Africa, India and Indonesia) during the period of 2004-2013. The total number of observations is 8574 . We used panel data analysis because 
both cross-sectional and time-section dimensions exist. One of the independent variables is the lag of dependent variables (total debt leverage) in our models; therefore, dynamic panel data was selected rather than static panel data. The Arellano-Bond linear dynamic panel data estimation model (Arellano\& Bond, 1991) is used in order to solve the endogeneity, heteroskedasticity, and autocorrelation problems. This model, designed by Arellano-Bover (1995) and Blundell-Bond (1998), is especially useful for situations with small T and large N panels. Both models can be used safely on datasets having such characteristics (Roodman, 2006). In our study, since $T=10$ and $N=954$, these conditions have been satisfied.

Conducting the unit root tests of the variables, we checked that the unit root problem does not exist since the $\mathrm{HO}$ hypothesizes which states. $\mathrm{HO}$ is rejected for all variables.

On the other hand, the Arellano-Bond linear dynamic panel data estimation model is conducted by using the xtabond 2 command. In our all models, we had to use instrumental variables because of the endogeneity problem. This command also provides that endogenous and autocorrelation tests are applied as well. The Sargan test is conducted to test the instrumental variables used for the solution of the endogeneity problem. The Sargan test statistic is inconsistent in the robust onestep GMM (Roodman, 2006). If the robust GMM is used in the models, then the Sargan test cannot be used for this purpose. The Hansen test was developed to solve this problem, and thus replaced the Sargan test. The HO hypothesis in the Hansen test (stating that instruments used in models are valid) is accepted for our all models.

Subsequently, Arellano-Bond tests AR (1) and AR (2) are conducted to check the auto correlation problems. In the AR (1) test, the lagged value of the dependent variable used in the model causes the rejection of the HO hypothesis, which states that there is no auto correlation. (The presence of the lagged dependent variable DRit-1 gives rise to autocorrelation.) Therefore, the AR (2) test needs to be checked (Roodman, 2006). The HO hypothesis is based on no autocorrelation in the AR (2) test for our all models. Moreover, Wald tests of all models have produced statistically significant results. All of these test results are given in the tables.

\subsection{Model and Variables}

Total debt leverage, which is measured as total debts/total assets, is used as the dependent variable in the study. The ten independent variables used in the developed model are: Total debt leverage in the previous year, natural logarithm of assets (sizea), growth of the natural logarithm of assets (growthl), growth of assets (growtha), tangibility (Tangible assets / Total assets), EBITDA (EBIDT / Total Assets), market price to book value ( $\mathrm{pb}$ ), real effective exchange rate (CPI based), GDP growth rate (gdpgrowth), Inflation (CPI) growth rate (infgrowth), and Industry median leverage ratio (indmedlev). 
Firm Specific and Macroeconomic Determinants of Capital Structure: Evidence from ...

In order to obtain the values of these variables, the Data Stream of the Thomson Reuters Database is used (2016).

The panel data model may be represented as follows:

$D R_{i t}=\alpha+B_{1} D R_{i t-1}+B_{2}$ Size $_{i t}+B_{3}$ Tang $_{i t}+B_{4}$ Growth $_{i t}+B_{5}$ EBITDA $_{i t}+B_{6} P B_{i t}+$

$B_{7}$ ExchangeRate $_{i t}+B_{8}$ GDP Growth ${ }_{i t}+B_{\text {g }}$ Inflation $_{i t}+B_{10}$ IndustryMedian $_{i t}+\mu_{t}+U_{i}+\varepsilon_{i t}(1)$

Where $\mathrm{i}=1, \ldots \mathrm{N}$ (number of firms), $\mathrm{t}=1, \ldots \mathrm{T}$ (time period). In the equation, $\mathrm{DR}_{\text {it }}$ denotes total debts over total assets, explaining the external financing choices of companies; $\mu \mathrm{t}$ is a time-fixed effect; $v i$ is an unobserved firms' fixed effect; $\varepsilon$ it is a serially uncorrelated error term.

\subsection{Descriptive Statistics}

The descriptive statistics of the variables used in the model are given in the table 1 $A$ and $B$ below.

\section{Table 1 A. Descriptive Statistics (all countries, Turkey, Brazil)}

\begin{tabular}{lccccccccc}
\hline Variables & & All & \multicolumn{3}{c}{ Tur } & \multicolumn{3}{c}{ Bra } \\
\hline & $\mathrm{N}$ & Mean & $\mathrm{SD}$ & $\mathrm{N}$ & Mean & $\mathrm{SD}$ & $\mathrm{N}$ & Mean & $\mathrm{SD}$ \\
\hline tdebt & 10,040 & 0.366 & 2.993 & 1,480 & 0.228 & 0.353 & 1,530 & 0.764 & 6.294 \\
\hline indmedlev & 9,540 & 0.242 & 0.117 & 1,410 & 0.185 & 0.115 & 1,360 & 0.275 & 0.0981 \\
\hline sizea & 10,040 & 16.04 & 3.246 & 1,480 & 12.76 & 1.588 & 1,530 & 13.94 & 2.128 \\
\hline growthl & 9,036 & 0.00925 & 0.0364 & 1,332 & 0.00864 & 0.0181 & 1,377 & 0.00703 & 0.0215 \\
\hline growtha & 9,036 & 1.164 & 54.77 & 1,332 & 0.147 & 0.361 & 1,377 & 0.148 & 0.561 \\
\hline tang & 10,036 & 0.365 & 0.220 & 1,480 & 0.366 & 0.202 & 1,530 & 0.357 & 0.230 \\
\hline ebitda & 10,035 & 0.136 & 1.184 & 1,480 & 0.119 & 0.244 & 1,525 & 0.122 & 0.214 \\
\hline pb & 10,030 & 38.40 & 554.2 & 1,480 & 1.483 & 8.433 & 1,525 & 237.4 & 1,404 \\
\hline gdpgrowth & 10,040 & 0.0571 & 0.0289 & 1,480 & 0.0494 & 0.0436 & 1,530 & 0.0396 & 0.0214 \\
\hline infgrowth & 10,040 & 0.0184 & 0.275 & 1,480 & -0.0857 & 0.231 & 1,530 & -0.0328 & 0.216 \\
\hline exch & 10,040 & 91.21 & 7.984 & 1,480 & 91.41 & 5.073 & 1,530 & 85.16 & 13.81 \\
\hline
\end{tabular}

Table1 B. Descriptive Statistics (South Africa, Indonesia, and India)

\begin{tabular}{llllllllll}
\hline Variables & & \multicolumn{1}{c}{$\mathrm{SA}$} & & & \multicolumn{2}{c}{ Id } & \multicolumn{3}{c}{ In } \\
\hline & $\mathrm{N}$ & Mean & $\mathrm{SD}$ & $\mathrm{N}$ & Mean & $\mathrm{SD}$ & $\mathrm{N}$ & Mean & SD \\
\hline tdebt & 1,370 & 0.173 & 0.205 & 1,980 & 0.412 & 3.795 & 3,680 & 0.302 & 0.270 \\
\hline indmedlev & 1,220 & 0.127 & 0.0669 & 1,870 & 0.255 & 0.113 & 3,680 & 0.284 & 0.105 \\
\hline sizea & 1,370 & 14.38 & 2.336 & 1,980 & 20.75 & 1.771 & 3,680 & 16.32 & 1.708 \\
\hline growthl & 1,233 & 0.0141 & 0.0787 & 1,782 & 0.00638 & 0.0237 & 3,312 & 0.0102 & 0.0257 \\
\hline growtha & 1,233 & 2.761 & 51.65 & 1,782 & 0.647 & 11.17 & 3,312 & 1.680 & 84.40 \\
\hline tang & 1,366 & 0.308 & 0.228 & 1,980 & 0.384 & 0.231 & 3,680 & 0.378 & 0.209 \\
\hline ebitda & 1,370 & 0.211 & 0.953 & 1,980 & 0.0874 & 2.521 & 3,680 & 0.148 & 0.145 \\
\hline pb & 1,370 & 3.526 & 22.91 & 1,975 & 2.688 & 24.73 & 3,680 & 2.937 & 34.50 \\
\hline gdpgrowth & 1,370 & 0.0331 & 0.0202 & 1,980 & 0.0589 & 0.00732 & 3,680 & 0.0754 & 0.0210 \\
\hline infgrowth & 1,370 & 0.0148 & 0.273 & 1,980 & 0.0208 & 0.293 & 3,680 & 0.0817 & 0.287 \\
\hline exch & 1,370 & 93.77 & 8.177 & 1,980 & 92.15 & 5.917 & 3,680 & 92.18 & 4.640 \\
\hline
\end{tabular}


For the years 2004-2013, the average leverage ratio is $22.8 \%$ for Turkish companies, $76.4 \%$ for Brazilian companies, $17.3 \%$ for South African companies, $30.2 \%$ for Indian companies and $41.2 \%$ for Indonesian companies.

The descriptive statistics of the variables used in the model are given in the table below. For the years 2004-2013, the average leverage ratio is $22.8 \%$ for Turkish companies, $76.4 \%$ for Brazilian companies, $17.3 \%$ for South African companies, $30.2 \%$ for Indian companies and $41.2 \%$ for Indonesian companies.

The correlation analyses (Table 2 ) between the five countries show no significant relationship that will affect the outcomes of the model. Similarly, a separate analysis for each country generates the same results.

Table 2. Correlations Matrix

\begin{tabular}{|c|c|c|c|c|c|c|c|c|c|c|c|c|c|}
\hline $\begin{array}{l}\text { (obs= } \\
8570)\end{array}$ & $\frac{\square}{\frac{0}{0}}$ & $\begin{array}{l}\frac{4}{0} \\
\underline{0}\end{array}$ & $\frac{\overrightarrow{0}}{\frac{0}{0}}$ & 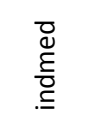 & $\frac{\mathbb{N}}{\mathbb{N}}$ & 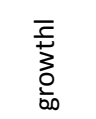 & $\begin{array}{l}\stackrel{0}{\frac{\pi}{7}} \\
\frac{3}{0} \\
\frac{0}{00}\end{array}$ & 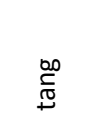 & $\begin{array}{l}\frac{\pi}{0} \\
\frac{0}{0} \\
\frac{0}{0}\end{array}$ & 용 & $\frac{\mathscr{d}}{\tilde{n}}$ & 응 $\frac{5}{\text { 苟 }}$ & $\stackrel{\underline{5}}{\stackrel{5}{3}}$ \\
\hline Idebt & 0.072 & 1 & & & & & & & & & & & \\
\hline sdebt & 0.996 & -0.015 & 1 & & & & & & & & & & \\
\hline indmed & 0.077 & 0.255 & 0.055 & 1 & & & & & & & & & \\
\hline sizea & -0.072 & 0.057 & -0.077 & 0.167 & 1 & & & & & & & & \\
\hline growthl & -0.031 & -0.021 & -0.029 & -0.021 & -0.004 & 1 & & & & & & & \\
\hline growtha & -0.002 & -0.011 & -0.001 & -0.010 & -0.005 & 0.559 & & & & & & & \\
\hline tang & -0.016 & 0.206 & -0.034 & 0.226 & 0.106 & -0.036 & -0.008 & 1 & & & & & \\
\hline ebitda & -0.014 & -0.018 & -0.012 & -0.036 & -0.012 & -0.105 & -0.005 & -0.044 & 1 & & & & \\
\hline $\mathrm{pb}$ & -0.005 & 0.008 & -0.006 & -0.005 & -0.022 & -0.009 & -0.001 & 0.002 & 0.012 & 1 & & & \\
\hline sales & 0.079 & -0.170 & 0.094 & -0.165 & 0.043 & -0.051 & -0.020 & -0.283 & 0.101 & -0.011 & 1 & & \\
\hline $\begin{array}{l}\text { Gdp } \\
\text { growth }\end{array}$ & -0.015 & 0.062 & -0.020 & 0.153 & 0.207 & 0.053 & 0.002 & 0.046 & 0.027 & -0.035 & -0.024 & 1 & \\
\hline $\begin{array}{l}\text { Inf } \\
\text { growth }\end{array}$ & 0.002 & 0.007 & 0.001 & 0.043 & 0.085 & 0.040 & 0.021 & -0.013 & 0.009 & -0.040 & 0.009 & 0.248 & 1 \\
\hline exch & -0.002 & -0.018 & -0.001 & -0.029 & 0.127 & -0.000 & -0.003 & -0.026 & 0.018 & -0.122 & 0.003 & 0.164 & 0.153 \\
\hline
\end{tabular}

\section{Estimation Results and Discussion}

\subsection{General Model}

In this study, eight models are used in the general model (the overall sample period). We analyzed the five countries' companies together in the first model. In the second model, Indonesia is excluded and four countries are analyzed. Afterwards, each country's companies are studied in separate models. As the number of firms in India for the data correlating to 2004 and 2005 could not be obtained, we added another model that analyzes the period between 2006 and 2013. Data could be obtained from only 368 Indian firms for the period between 2004 and 2013 compared to 1,149 firms for the period between 2006 and 2013. 
Firm Specific and Macroeconomic Determinants of Capital Structure: Evidence from ...

In the model with all five countries' companies, only three variables have statistically significant and positive relationships with the leverage ratio (Table $3 \mathrm{~A}$ and $\mathrm{B}$ ). These variables are lagged leverage ratio, EBITDA and changes in expected inflation rate.

Table3A. System GMM Dynamic Panel Analysis Based on the ArellanoBover/Blundell-Bond estimator for the Period 2004-2013

\begin{tabular}{|c|c|c|c|c|}
\hline & Model (1) & Model (2) & Model (3) & Model (4) \\
\hline Variables & Allcountries & 4countries & Turkey & Brazil \\
\hline \multirow{2}{*}{ L.tdebt } & $1.133^{* * *}$ & $1.149 * * *$ & $1.302 * * *$ & $1.170^{* * *}$ \\
\hline & $(0.00682)$ & $(0.00169)$ & $(0.152)$ & $(0.00447)$ \\
\hline \multirow{2}{*}{ sizea } & -0.00886 & -0.00553 & $0.0116^{* *}$ & $0.0159 * *$ \\
\hline & $(0.00671)$ & $(0.00879)$ & $(0.00518)$ & $(0.00839)$ \\
\hline \multirow{2}{*}{ growthl } & -9.288 & -1.336 & $1.579 * * *$ & \\
\hline & $(9.086)$ & $(0.973)$ & $(0.338)$ & \\
\hline \multirow{2}{*}{ tang } & -0.951 & -0.125 & -0.0202 & -0.138 \\
\hline & $(0.871)$ & $(0.124)$ & $(0.0338)$ & $(0.109)$ \\
\hline \multirow{2}{*}{ ebitda } & $0.189 * * *$ & $-0.190 *$ & $-0.693 * * *$ & $-0.978 * *$ \\
\hline & $(0.0431)$ & $(0.104)$ & $(0.179)$ & $(0.501)$ \\
\hline \multirow{2}{*}{$\mathrm{pb}$} & $8.75 e-06$ & $1.08 \mathrm{e}-05$ & $-0.000307^{*}$ & $1.29 \mathrm{e}-05$ \\
\hline & (9.49e-06) & $(1.44 \mathrm{e}-05)$ & $(0.000181)$ & $(1.16 e-05)$ \\
\hline \multirow{2}{*}{ exch } & 0.00347 & 0.00113 & -0.00112 & -0.00125 \\
\hline & $(0.00318)$ & $(0.00169)$ & $(0.000709)$ & $(0.000965)$ \\
\hline \multirow{2}{*}{ gdpgrowth } & -0.00694 & -0.169 & $0.183^{* *}$ & 0.270 \\
\hline & $(0.361)$ & $(0.119)$ & $(0.0834)$ & $(0.730)$ \\
\hline \multirow{2}{*}{ infgrowth } & 0.0391* & $0.0205^{*}$ & $0.0680 * * *$ & $0.0820 * *$ \\
\hline & $(0.0226)$ & $(0.0120)$ & $(0.0239)$ & $(0.0354)$ \\
\hline \multirow{2}{*}{ indmedlev } & 0.755 & 0.170 & -0.220 & 0.116 \\
\hline & $(0.601)$ & $(0.194)$ & $(0.185)$ & $(0.193)$ \\
\hline \multirow{2}{*}{ growtha } & & & & $-0.240 * *$ \\
\hline & & & & $(0.121)$ \\
\hline Observations & 8,574 & 6,894 & 1,269 & 1,219 \\
\hline Number of id & 954 & 767 & 141 & 136 \\
\hline e(ar2) & -1.006 & 0.960 & -1.018 & 1.097 \\
\hline$e(\operatorname{ar} 2 p)$ & 0.315 & 0.337 & 0.309 & 0.272 \\
\hline e(hansen) & 6.101 & 7.684 & 9.757 & 6.246 \\
\hline e(hansenp) & 0.297 & 0.175 & 0.203 & 0.396 \\
\hline e(chi2) & $412309 * * *$ & $966066 * * *$ & $2642 * * *$ & $4.384 \mathrm{e}+06 * * *$ \\
\hline esttype & system & system & system & System \\
\hline vcetype & Robust & Robust & Corrected & Corrected \\
\hline robust & robust & robust & robust & Robust \\
\hline
\end{tabular}

Lagged Leverage Ratio: A statistically significant positive relationship was found between the lagged debt value and debt ratio for all of the fragile countries except Indonesia where this relationship was negative. In Indonesia, the firms with higher 
debt burdens tended to decrease their debts contrary to expectations. In the other four countries, those firms which received higher levels of debts continued to receive more debts.

Profitability (EBITDA): The positive relationship between profitability and leverage ratio that supports the trade-off theory is observed only for Indonesia. On the other hand, there is a negative relationship between these variables for the other four countries that suggests the financial hierarchy theory applies to them. When Indonesia is excluded from the model, a negative relationship is observed between EBITDA and leverage ratio for the remaining four countries. This implies that these countries, with the exception of Indonesia, prefer using their internal resources in financing their needs.

Price to Book Value: The negative relationship between price to book value and leverage ratio for Turkey and South Africa also supports the trade-off theory. In these two countries, the use of internal resources was preferred by the companies that improved their market values. On the other hand, there is a positive relationship between these variables for India that suggests the financial hierarchy theory.

Growth Rates: Two different variables are used to represent growth rates in the models. The first one is the growth rate of the natural logarithm of total assets (growthl) where the second one is the growth rate of the value of the total assets (growtha). The statistically significant relationship between growth rate and leverage ratio for Turkey and India is positive, but it is negative for Brazil. This suggests that financial hierarchy is prevalent in Turkey and India but the trade-off theory prevails for Brazil.

Firm Size: A positive and statistically significant relationship between firm size and leverage ratio, which is consistent with the trade-off theory, is seen for Turkey, India and Brazil. In the trade-off theory, the smaller default risk of bigger firms may enable them to use more debt financing.

Inflation Rate: A positive and statistically significant relationship between expected inflation rate and leverage ratio is found for the model with all countries. The same positive relationship is observed in the models with individual countries, with the exception of Indonesia and India.

These results are consistent with Taggart's (1985) theory which states that with the existence of a strong relationship between inflation and market interest rates, a high inflation rate causing a strong tax shield effect will encourage firms to use more debt. Taggart's (1985) theory is in line with the trade-off theory. The findings of Frank and Goyal (2009), Sett and Sarkhel (2010), and Hanousek and Shamshur (2011) support this theory. Despite of these three countries (Turkey, Brazil, and South Africa) a negative and statistically significant relationship between expected inflation rate and leverage ratio is found for India and suggests the financial hierarchy theory. 
Firm Specific and Macroeconomic Determinants of Capital Structure: Evidence from ...

Table 3 B. System GMM Dynamic Panel Analysis based on the ArellanoBover/Blundell-Bond estimator for the Period 2004-2013

\begin{tabular}{|c|c|c|c|c|}
\hline & Model (5) & Model (6) & Model (7) & Model (8) \\
\hline Variables & South Africa & Indonesia & India & India 2006 \\
\hline \multirow{2}{*}{ L.tdebt } & $0.572^{* * *}$ & $-0.772 * * *$ & $0.792 * * *$ & $0.569 * * *$ \\
\hline & $(0.159)$ & $(0.158)$ & $(0.156)$ & $(0.138)$ \\
\hline \multirow{2}{*}{ sizea } & -0.00471 & -0.0243 & $0.00727 * *$ & $0.00679 * * *$ \\
\hline & $(0.00609)$ & $(0.0457)$ & $(0.00324)$ & $(0.00203)$ \\
\hline \multirow[t]{2}{*}{ growthl } & -0.380 & & $0.540 * *$ & \\
\hline & $(0.274)$ & & $(0.242)$ & \\
\hline \multirow{2}{*}{ tang } & 0.0529 & 0.168 & 0.0676 & $0.178 * * *$ \\
\hline & $(0.0478)$ & $(0.314)$ & $(0.0500)$ & $(0.0521)$ \\
\hline \multirow{2}{*}{ ebitda } & $-0.0307^{* *}$ & $0.378 * * *$ & $-0.443 * *$ & $-0.360 * * *$ \\
\hline & $(0.0157)$ & $(0.0216)$ & $(0.210)$ & $(0.0889)$ \\
\hline \multirow[t]{2}{*}{$\mathrm{pb}$} & $-0.000189 * *$ & $8.23 e-05$ & $0.000246 * * *$ & $3.51 \mathrm{e}-05$ \\
\hline & (8.77e-05) & $(0.000207)$ & (4.35e-05) & $(6.78 \mathrm{e}-05)$ \\
\hline \multirow{2}{*}{ exch } & 0.000975 & 0.00546 & $-0.000774 * *$ & $-0.000755^{* *}$ \\
\hline & $(0.00105)$ & $(0.00910)$ & $(0.000405)$ & $(0.000357)$ \\
\hline \multirow{2}{*}{ gdpgrowth } & -0.337 & 0.458 & 0.221 & $0.187^{*}$ \\
\hline & $(0.260)$ & $(1.267)$ & $(0.203)$ & $(0.106)$ \\
\hline \multirow{2}{*}{ infgrowth } & $0.0502 *$ & -0.0391 & $-0.0170 * * *$ & $-0.0155^{* * *}$ \\
\hline & $(0.0296)$ & $(0.0427)$ & $(0.00571)$ & $(0.00554)$ \\
\hline \multirow[t]{2}{*}{ indmedlev } & $0.399 * * *$ & $1.520 * *$ & $0.102^{*}$ & $0.231 * * *$ \\
\hline & $(0.157)$ & $(0.724)$ & $(0.0627)$ & $(0.0823)$ \\
\hline \multirow{2}{*}{ growtha } & \multicolumn{3}{|c|}{-0.00251} & $0.000198^{* * *}$ \\
\hline & \multicolumn{3}{|c|}{$(0.0504)$} & (5.72e-05) \\
\hline Observations & 1,094 & 1,680 & 3,312 & 8,043 \\
\hline Number of id & 122 & 187 & 368 & 1,149 \\
\hline $\mathrm{e}(\operatorname{ar} 2)$ & -0.869 & -0.992 & 0.744 & 0.799 \\
\hline$e(\operatorname{ar} 2 p)$ & 0.385 & 0.321 & 0.457 & 0.424 \\
\hline e(hansen) & 8.144 & 4.370 & 17.70 & 6.575 \\
\hline e(hansenp) & 0.420 & 0.976 & 0.342 & 0.254 \\
\hline $\begin{array}{l}\text { e(chi2) } \\
\text { esttype }\end{array}$ & $\begin{array}{l}1366 * * * \\
\text { system }\end{array}$ & $\begin{array}{l}1247^{* * * *} \\
\text { system }\end{array}$ & $\begin{array}{l}17462 * * * \\
\text { system }\end{array}$ & $\begin{array}{l}11993 * * * \\
\text { system }\end{array}$ \\
\hline $\begin{array}{l}\text { vcetype } \\
\text { robust }\end{array}$ & $\begin{array}{l}\text { Robust } \\
\text { robust }\end{array}$ & $\begin{array}{cc}\text { Corrected } & \begin{array}{c}\text { Corrected } \\
\text { robust }\end{array} \\
\text { robust }\end{array}$ & & $\begin{array}{l}\text { Corrected } \\
\text { robust }\end{array}$ \\
\hline
\end{tabular}

Robuststandarderrors in parentheses ${ }^{* * *} \mathrm{p}<0.01,{ }^{* *} \mathrm{p}<0.05,{ }^{*} \mathrm{p}<0.10$

Exchange Rate: No statistically significant relationship is found between leverage ratio and real effective exchange rate, with the exception of India. The statistically significant relationship between the real effective exchange rate and leverage ratio for India is negative. As the Indian currency depreciated in real terms, the level of debts used by the firms increased. As will be discussed below, the relationship between these variables became significant if financial crisis is added to the model. 
Tangibility: No statistically significant relationship is found between leverage ratio and tangibility, with the exception of India. The statistically significant relationship between tangibility and leverage ratio for India is positive. This positive relationship is shown in the studies of Frank and Goyal (2009) and Stohs and Mauer (1996) and suggests the trade-off theory.

GDP Growth Rate: A positive and statistically significant relationship between GDP growth rate and leverage ratio is found for Turkey and India, despite the fact that the relationship is negative, which is consistent with the financial hierarchy theory. This positive relationship is shown in the studies of Frank and Goyal (2009) and Gajurel (2006).

Industry Median Leverage Ratio: As implied by the trade-off theory, a high level of industry median leverage ratio (causing a high debt ratio), a positive and statistically significant relationship is found between industry median leverage ratio and debt ratio for South Africa, India and Indonesia.

\subsection{Effects of Financial Crisis}

In this study, nine models are used in the Financial Crisis' Effects Model. The overall sample period is divided into two sub-periods: 1 ) the period of 2004-2008 is used to determine capital structure determinants before the global financial crisis (Table 4) and 2) the period of 2009-2013 is used to study the effects of the crisis on such determinants (Table 5). It is believed that the impact of the crisis will be felt one year later.

We also examined how the results would be affected when India and Indonesia were removed from the model singly or together in the general analysis as well as in the pre-crisis and post-crisis analyses. In the literature, it was maintained that the fragility of these two countries has declined for certain reasons and therefore, they can be exempted from the Fragile Five. India has secured positive results in its crackdown on inflation and current account deficit. Likewise, Indonesia has succeeded in lowering its current account deficit. For Morgan and Stanley economists, India and Indonesia have implemented, respectively, $85 \%$ and $65 \%$ of the reforms required for getting rid of their fragile status (Kennedy, 2015).

Profitability (EBITDA): The positive relationship between profitability and leverage ratio that supports the trade-off theory is observed during the post-crisis period. On the other hand, there is a negative relationship between these variables for the pre-crisis period that suggests the financial hierarchy theory applies to them. When Indonesia and India are excluded from the model together or separately, these relationships are observed to be the same between EBITDA and leverage ratio.

In the pre-crisis period, profitable firms place emphasis on internal resources for borrowing purposes. When the post-crisis period is examined for the five countries, it is seen that the firms with higher profitability tend to take on debts more. However, when Indonesia is removed from the post-crisis models, this relationship 
is found to be statistically not significant, and turns from positive to negative. For this reason, when Indonesia is removed from the model, it becomes impossible to interpret the model from this perspective.

Table 4.System GMM Dynamic Panel Analysis based on the ArellanoBover/Blundell-Bond estimator for the Period 2004-2013, the Pre-Crisis Period and the Post-Crisis Period

\begin{tabular}{llll}
\hline Allcountries & Model $(1)$ & Model $(9)$ & Model $(10)$ \\
\hline Variables & $2004-2013$ & Before crisis & After crisis \\
\hline L.tdebt & $1.133(0.00682)^{* * *}$ & $1.294(0.0181)^{* * *}$ & $1.122(0.0132)^{* * *}$ \\
\hline sizea & $-0.00886(0.00671)$ & $-0.00995(0.00323)^{* * *}$ & $0.00545(0.0153)$ \\
\hline growthl & $-9.288(9.086)$ & $-2.010(0.635)^{* * *}$ & $-36.16(33.71)$ \\
\hline tang & $-0.951(0.871)$ & $-0.140(0.0404)^{* * *}$ & $-1.286(1.144)$ \\
\hline ebitda & $0.189(0.0431)^{* * *}$ & $-0.360(0.0166)^{* * *}$ & $0.970(0.0993)^{* * *}$ \\
\hline pb & $8.75 \mathrm{e}-06(9.49 \mathrm{e}-06)$ & $1.13 \mathrm{e}-05(1.55 \mathrm{e}-05)$ & $-5.39 \mathrm{e}-05(7.55 \mathrm{e}-05)$ \\
\hline exch & $0.00347(0.00318)$ & $0.00234(0.000643)^{* * *}$ & $0.00209(0.00256)$ \\
\hline gdpgrowth & $-0.00694(0.361)$ & $0.169(0.184)$ & $1.008(1.229)$ \\
\hline infgrowth & $0.0391(0.0226)^{*}$ & $0.0366(0.0180)^{* *}$ & $0.0975(0.0886)$ \\
\hline indmedlev & $0.755(0.601)$ & $-0.0391(0.0496)$ & $0.744(0.576)$ \\
\hline Observations & 8,574 & 3,807 & 4,767 \\
\hline Number of id & 954 & 954 & 954 \\
\hline e(ar2) & -1.006 & 0.975 & -1.335 \\
\hline e(ar2p) & 0.315 & 0.329 & 0.182 \\
\hline $\mathrm{e}($ hansen) & 6.101 & 9.136 & 5.157 \\
\hline e(hansenp) & 0.297 & 0.243 & 0.397 \\
\hline e(chi2) & $412309^{* * *}$ & $14641^{* * *}$ & $40290^{* * *}$ \\
\hline esttype & system & system & system \\
\hline vcetype & Robust & Corrected & Robust \\
\hline robust & robust & robust & robust \\
\hline Robuststandarderrors in parentheses*** $p<0.01,{ }^{* *} p<0.05,{ }^{*} \mathrm{p}<0.10$ & \\
\hline
\end{tabular}

Price to Book Value: There is no significant relationship between price to book value ratio and leverage during all periods.

Growth Rates: When Indonesia is removed from the model, the statistically significant relationship between growth rate and leverage ratio for the pre-crisis period is negative, but it is positive for post-crisis period. This suggests that financial hierarchy is prevalent in the post-crisis period where the trade-off theory prevails for the pre-crisis period.

Firm Size: There is no significant relationship between firm size and leverage during all periods and the post-crisis period. A positive and statistically significant relationship between firm size and leverage ratio, which is consistent with the trade-off theory, is seen only for the pre-crisis period. This negative relationship changed to positive in the post-crisis period but is not significantly related to 
leverage. The trade-off theory purports that big companies which have smaller default risk can use more debt financing.

Table 5.System GMM Dynamic Panel Analysis based on the ArellanoBover/Blundell-Bond estimator for the Period 2004-2013 and the PreCrisis Period

\begin{tabular}{|c|c|c|c|c|c|}
\hline & Model (1) & Model (9) & Model (11) & Model (12) & Model (13) \\
\hline Variables & Allcountries & Beforecrisis & Beforecrisisnoid & Beforecrisisnoin & Beforecrisisnoin\&id \\
\hline \multirow[t]{2}{*}{ L.tdebt } & $1.133^{* * *}$ & $1.294^{* * *}$ & $1.314 * * *$ & $1.274^{* * *}$ & $1.327^{* * *}$ \\
\hline & (0.00682) & $(0.0181)$ & $(0.0157)$ & $(0.0144)$ & $(0.00443)$ \\
\hline \multirow[t]{2}{*}{ sizea } & -0.00886 & $-0.00995^{* * *}$ & -0.00365 & $-0.0111 * * *$ & -0.000991 \\
\hline & $(0.00671)$ & $(0.00323)$ & $(0.00351)$ & $(0.00426)$ & $(0.00596)$ \\
\hline \multirow[t]{2}{*}{ growthl } & -9.288 & $-2.010 * * *$ & -1.250 & $-2.107 * * *$ & -1.534 \\
\hline & $(9.086)$ & $(0.635)$ & (1.094) & $(0.507)$ & $(1.145)$ \\
\hline \multirow[t]{2}{*}{ tang } & -0.951 & $-0.140 * * *$ & $-0.0991 * * *$ & $-0.109 * *$ & -0.0340 \\
\hline & $(0.871)$ & $(0.0404)$ & $(0.0372)$ & $(0.0545)$ & $(0.0634)$ \\
\hline \multirow[t]{2}{*}{ ebitda } & $0.189 * * *$ & $-0.360 * * *$ & -0.141 & $-0.363^{* * *}$ & -0.194 \\
\hline & $(0.0431)$ & $(0.0166)$ & $(0.134)$ & $(0.0139)$ & $(0.162)$ \\
\hline \multirow[t]{2}{*}{$\mathrm{pb}$} & $8.75 e-06$ & $1.13 e-05$ & $-2.30 e-06$ & $1.77 e-05$ & $2.26 \mathrm{e}-06$ \\
\hline & (9.49e-06) & $(1.55 \mathrm{e}-05)$ & (1.59e-05) & $(1.64 \mathrm{e}-05)$ & (1.59e-05) \\
\hline \multirow[t]{2}{*}{ exch } & 0.00347 & $0.00234^{* * *}$ & $0.00105^{*}$ & $0.00251^{* * *}$ & 0.000455 \\
\hline & $(0.00318)$ & $(0.000643)$ & $(0.000579)$ & $(0.000700)$ & $(0.000540)$ \\
\hline \multirow[t]{2}{*}{ gdpgrowth } & -0.00694 & 0.169 & -0.323 & 0.0427 & -0.165 \\
\hline & $(0.361)$ & $(0.184)$ & $(0.216)$ & $(0.388)$ & $(0.235)$ \\
\hline \multirow[t]{2}{*}{ infgrowth } & $0.0391^{*}$ & $0.0366^{* *}$ & 0.0137 & 0.0400 & $0.0711^{* * *}$ \\
\hline & $(0.0226)$ & $(0.0180)$ & (0.0169) & $(0.0250)$ & $(0.0211)$ \\
\hline \multirow[t]{2}{*}{ indmedlev } & 0.755 & -0.0391 & -0.0712 & -0.0129 & $-0.0898^{*}$ \\
\hline & $(0.601)$ & $(0.0496)$ & $(0.0451)$ & $(0.0825)$ & $(0.0566)$ \\
\hline Observations & 8,574 & 3,807 & 3,062 & 2,335 & 1,590 \\
\hline Number of id & 954 & 954 & 767 & 586 & 399 \\
\hline e(ar2) & -1.006 & 0.975 & 1.093 & 0.860 & 0.941 \\
\hline e(ar2p) & 0.315 & 0.329 & 0.274 & 0.390 & 0.347 \\
\hline e(hansen) & 6.101 & 9.136 & 9.199 & 5.912 & 9.960 \\
\hline e(hansenp) & 0.297 & 0.243 & 0.239 & 0.116 & 0.191 \\
\hline e(chi2) & $412309 * * *$ & $14641 * * *$ & $23308^{* * *}$ & $13457^{* * *}$ & $119884 * * *$ \\
\hline esttype & system & system & system & system & system \\
\hline vcetype & Robust & Corrected & Corrected & Corrected & Corrected \\
\hline robust & robust & robust & robust & robust & robust \\
\hline
\end{tabular}

Robuststandarderrors in parentheses ${ }^{* * *} p<0.01,{ }^{* *} p<0.05,{ }^{*} p<0.10$

Tangibility: No statistically significant relationship is found between leverage ratio tangibility during the post-crisis period. On the other hand, the statistically significant relationship between tangibility and leverage ratio is negative for the pre-crisis period. This negative relationship is shown in the studies of Frank and Goyal (2009) and Stohs and Mauer (1996) and thus suggests the financial hierarchy theory. 
Firm Specific and Macroeconomic Determinants of Capital Structure: Evidence from ...

Table 6. System GMM Dynamic Panel Analysis Based on the ArellanoBover/Blundell-Bond estimator for the Period 2004-2013 and the PostCrisis Period

\begin{tabular}{|c|c|c|c|c|c|}
\hline & Model (1) & Model (10) & Model (14) & Model (15) & Model (16) \\
\hline Variables & Allcountries & Aftercrisis & Aftercrisisnoid & Aftercrisisnoin & Aftercrisisnoin\&id \\
\hline \multirow{2}{*}{ L.tdebt } & $1.133 * * *$ & $1.122 * * *$ & $1.171 * * *$ & $1.132 * * *$ & $1.156^{* * *}$ \\
\hline & $(0.00682)$ & $(0.0132)$ & $(0.00225)$ & $(0.0146)$ & $(0.00154)$ \\
\hline \multirow{2}{*}{ sizea } & -0.00886 & 0.00545 & 0.00176 & -0.00908 & 0.00538 \\
\hline & $(0.00671)$ & $(0.0153)$ & $(0.00324)$ & $(0.0112)$ & $(0.00400)$ \\
\hline \multirow{2}{*}{ growthl } & -9.288 & -36.16 & $0.609 * *$ & 7.829 & -0.495 \\
\hline & $(9.086)$ & $(33.71)$ & $(0.290)$ & $(16.73)$ & $(0.908)$ \\
\hline \multirow{2}{*}{$\operatorname{tang}$} & -0.951 & -1.286 & -0.0128 & 0.361 & -0.0174 \\
\hline & $(0.871)$ & $(1.144)$ & $(0.0314)$ & $(0.553)$ & $(0.0387)$ \\
\hline \multirow{2}{*}{ ebitda } & $0.189 * * *$ & $0.970 * * *$ & -0.256 & $0.846^{* * *}$ & -0.201 \\
\hline & $(0.0431)$ & $(0.0993)$ & $(0.307)$ & $(0.121)$ & $(0.238)$ \\
\hline \multirow{2}{*}{$\mathrm{pb}$} & $8.75 e-06$ & $-5.39 e-05$ & $2.17 e-06$ & $-5.31 e-06$ & $-1.49 e-05$ \\
\hline & $(9.49 e-06)$ & (7.55e-05) & $(2.15 e-05)$ & (5.30e-05) & $(1.87 e-05)$ \\
\hline \multirow{2}{*}{ exch } & 0.00347 & 0.00209 & $-0.000320^{*}$ & -0.00177 & $-0.000878^{* *}$ \\
\hline & $(0.00318)$ & $(0.00256)$ & $(0.000194)$ & $(0.00227)$ & $(0.000414)$ \\
\hline \multirow{2}{*}{ gdpgrowth } & -0.00694 & 1.008 & 0.0495 & -0.382 & 0.147 \\
\hline & $(0.361)$ & $(1.229)$ & $(0.0717)$ & $(1.259)$ & $(0.114)$ \\
\hline \multirow{2}{*}{ infgrowth } & $0.0391^{*}$ & 0.0975 & -0.00454 & -0.00638 & 0.0208 \\
\hline & $(0.0226)$ & $(0.0886)$ & $(0.00997)$ & $(0.125)$ & $(0.0180)$ \\
\hline \multirow{2}{*}{ indmedlev } & 0.755 & 0.744 & -0.0277 & 0.00198 & 0.00966 \\
\hline & $(0.601)$ & $(0.576)$ & $(0.0327)$ & $(0.323)$ & $(0.0795)$ \\
\hline Observations & 8,574 & 4,767 & 3,832 & 2,927 & 1,992 \\
\hline Number of id & 954 & 954 & 767 & 586 & 399 \\
\hline $\mathrm{e}(\operatorname{ar} 2)$ & -1.006 & -1.335 & -1.112 & -1.103 & -1.114 \\
\hline $\mathrm{e}(\operatorname{ar} 2 \mathrm{p})$ & 0.315 & 0.182 & 0.266 & 0.270 & 0.265 \\
\hline e(hansen) & 6.101 & 5.157 & 19.38 & 5.223 & 7.789 \\
\hline e(hansenp) & 0.297 & 0.397 & 0.151 & 0.389 & 0.168 \\
\hline e(hansen_df) & 5 & 5 & 14 & 5 & 5 \\
\hline e(chi2) & 412309 & 40290 & 402664 & 7912 & 673197 \\
\hline $\mathrm{e}(\mathrm{chi} 2 \mathrm{p})$ & 0 & 0 & 0 & 0 & 0 \\
\hline esttype & system & system & system & system & system \\
\hline vcetype & Robust & Robust & Corrected & Corrected & Corrected \\
\hline robust & robust & robust & robust & robust & robust \\
\hline
\end{tabular}

Inflation Rate: A positive and statistically significant relationship between expected inflation rate and leverage ratio is found that supports the trade-off theory for the model during all years. The findings are the same for the pre-crisis period 20042008. On the other hand, the growth rate is positive but not significantly related to leverage during the post-crisis period. 
Exchange Rate: The statistically significant relationship between exchange rate and leverage ratio for the pre-crisis period is positive. When Indonesia is excluded from the model, there is a negative statistically significant relationship between these ratios during the post-crisis period. Any decrease in the real effective exchange rate means that the currency in question suffers from real depreciation and the prices of the goods in the respective country decrease in terms of other currencies. As a result, the competitiveness of this country increases in international trade.

Firms tend to borrow debts while the country's currency is gaining value in the precrisis period, but they borrow less while the currency in question is gaining value in the post-crisis period. From another perspective, firms tend to borrow less as their country's competitiveness increases in international trade as a result of a decline in the exchange rates in the pre-crisis period, but they start to borrow more when their country's competitiveness increases as a result of a decline in the exchange rate in the post-crisis period. In the pre-crisis period, there was a significant flow of foreign capital into these countries in the form of debts due to the lower financing costs in international markets in the pre-crisis period, and, as a result, the national currencies gained in value against foreign currencies. During the crisis and in the post-crisis period, international trade suffered from stagnation and the markets of developing countries lost their vitality. In an effort to revive the developing countries' markets, funds were injected into the markets. These funds were channeled to developing countries with higher returns on investment.

The currencies of these countries managed to preserve their value against foreign currencies despite high inflation rates and even became more valuable than foreign currencies until 2011. As of that year, these currencies started to lose value, particularly due to the recovering US economy. In the post-crisis period, the firms which had taken on debts in terms of foreign currencies (especially in US dollars and Euros) encountered a huge increase in their debts in terms of their national currencies as these currencies lost value against foreign currencies. This may explain the negative relationship in the post-crisis models. As the national currency continued to lose value, the firms' debts in terms of local currency increased.

GDP Growth Rate: No statistically significant relationship is found between GDP growth ratio and leverage ratio during the post-crisis and the pre-crisis periods.

Industry Median Leverage Ratio: No statistically significant relationship is found between leverage ratio and industry median leverage ratio during the post-crisis and the pre-crisis periods.

\section{Conclusion}

The factors affecting capital structure were assessed along with micro and macro variables for the countries referred to as the Fragile Five, namely Brazil, Turkey, South Africa, India and Indonesia. The micro variables included in the model were the debt taken in the previous year, firm size, growth, industry debt average, 
tangibility and profitability ratio while GDP growth, inflation and exchange rate change were included in the model as macroeconomic variables. Also, the effects of financial crises were analyzed by treating pre- and post-2008 crisis periods separately. Given the fact that India and Indonesia were considerably successful in minimizing their fragility, these countries were excluded from certain models.

It was observed that the non-inclusion of Indonesia in the model differentiated the results and led to more significant results while the removal of India from the models made virtually no effect on the results. Therefore, the four-country models which do not include Indonesia are more significant.

In the model, which included Indonesia, the negative relationship between profitability and debt ratio (observed in the pre-crisis period), became positive in the post-crisis period. When Indonesia was removed from the model, this positive relationship became negative, but as it was not statistically significant, the role of Indonesia in this change couldn't be fully understood. The model where the preand post-crisis periods were assessed produced a similar effect. The relationship was found to be positive in the model, which included all five countries, but it turned negative when Indonesia was removed. When the pre-crisis (2004-2008) and post-crisis (2009-2013) models were analyzed in conjunction with the general models (2004-2013), it was noted that the negative relationship was stronger in the pre-crisis period and it lost its intensity and turned positive in the post-crisis period. The financial problems encountered in the post-crisis period as well as the decline in financing via internal resources encouraged firms to take on debts more.

The relationship between the real effective exchange rate and the debt ratio was positive in the pre-crisis five-country model, but it turned negative in the post-crisis model from which Indonesia was removed. Firms tend to borrow more as the national currency gains value against foreign currencies thanks to economic vitality and the rise in foreign loans in the pre-crisis period. Likewise, the firms took on considerable amounts of debt in terms of foreign currencies due to low-cost financing attributable to the increase in the supply of funds in the international markets during and immediately after the crisis. As the national currencies started to lose value after 2011, the firms' debts increased substantially in terms of national currencies. As a result, it can be argued that borrowing increased in the periods when there was rapid inflow of money into the country before and immediately after the crisis; the national currency gained value until 2011 and there was a negative relationship between these two variables. As noted in the IMF's report (Global Financial Stability Report, October 2015), the share of EM corporate debts in the GDP declined to attain a certain level of stability between 2009 and 2011, but started to increase after 2011. It can be suggested that the reason for the increase in the corporate debts' share in the GDP is the decline in the GDP in terms of US dollars for the countries whose national currencies depreciated. 
Conversely, a positive relationship was found between the inflation rate and the debt ratio for the general (2004-2013) and post-crisis models. Firms tended to borrow more as inflation increased. No statistically significant relationship could be found in the post-crisis period.

No statistically significant relationship was discovered between the GDP growth rate and the debt ratio for the pre-crisis, post-crisis and general models. This relationship was statistically significant only for Turkey for the period 2004-2013 and for India for the period 2006-2013. In these countries, it was found that firms tended to borrow more as the GDP growth rate increased.

The firms in the countries which enjoyed high growth rates before the crisis refrained from taking on debts and focused on growing in reliance on internal resources but they were forced to rely more on debts to attain higher growth rates after the crisis.

The negative relationship between firm size and debt implies that bigger firms tended to borrow less in the pre-crisis period. However, no statistically significant relationship was identified between these two variables for the post-crisis and general models. But this relationship was statistically significant and positive for Turkey, Brazil and India in the general model. Based on this fact, it can be argued that firms tend to borrow more in a post-crisis period rather than the pre-crisis period and bigger firms borrow more due to their lower default risk.

As is the case with firm size, the negative relationship between tangibility and the debt ratio indicates that the firms with higher tangibility tended to borrow less in the pre-crisis period. No statistically significant relationship was found between these two variables in the post-crisis and general models.

Except for Indonesia, there was always a positive relationship between the lagged debt value and the debt ratio for the pre-crisis, post-crisis and general models. The levels of debt usage in the previous period were influential over the existing debt levels.

No statistically significant relationship could be found between the PB and debt ratios for the pre-crisis, post-crisis and general models. However, there was a negative relationship for Turkey and South Africa, and a negative relationship for India for all periods.

No statistically significant relationship could be discovered between the industry debt average and the debt ratio for the pre-crisis, post-crisis and general models. However, there was a statistically significant and positive relationship for all periods for South Africa, Indonesia, and India. In these countries, the firms tend to borrow more in compliance with the industry average. 
Firm Specific and Macroeconomic Determinants of Capital Structure: Evidence from ...

\section{References}

Arellano, M., \& O. Bover. (1995). Another look at the instrumental variables estimation of error components models. Journal of Econometrics 68, 29-51. https://doi.org/10.1016/03044076(94)01642-D

Arellano, M. \& S. Bond. (1991). Some tests of specification for panel data: Monte Carlo evidence and an application to employment equations. The Review of Economic Studies, 58, 277-297. https://doi.org/10.2307/2297968

Bastos, D. D., Nakamura, W. T., \& Basso, L. F. C. (2009). Determinants of capital structure of publicly-traded companies in Latin America: the role of institutional and macroeconomic factors. Journal of international finance and economics, 9(3), 24-39.

http://dx.doi.org/10.1590/S1678-69712009000600005

Bokpin, G. A. (2009). Macroeconomic development and capital structure decisions of firms: evidence from emerging market economies. Studies in Economics and Finance, 26(2), 129142. http://dx.doi.org/10.1108/10867370910963055

Boodhoo, R., (2009). Capital structure and ownership structure: a review of literature. The Journal of Online Education, January Edition, 1- 8. Retrieved from https://ssrn.com/abstract $=1337041$

Bradley, M., Jarrell, G. A., \& Kim, E. H. (1984). On the Existence of an Optimal Capital Structure: Theory and Evidence. Journal of Finance, 39(3), 857-878. doi: 10.1111/j.15406261.1984.tb03680.x

Camara, O. (2012). Capital structure adjustment speed and macroeconomic conditions: U.S. MNCs and DCs. International Research Journal of Finance and Economics, 84, 106-120.

Chen, L., \& Zhao, X. S. (2005).Profitability, mean reversion of leverage ratios, and capital structure choices. Retrieved from http://ssrn.com/abstract=666992, March 17, 2011,

Degirmen, S., \& Gundogdu, Y., (2010). Financial Strategies of the Exporting Firms in Turkey. Business and Economics Research Journal, 1(4), 1-18. http://www.berjournal.com/?p=687

Demirhan, D. (2009). Firm Specific Factors That Affect Capital Structure: A Study on Services Sector Firms Traded on Istanbul Stock Exchange. Ege Academic Review, 9(2), 677-697. http://www.onlinedergi.com/MakaleDosyalari/51/PDF2009 2 15.pdf

Dinçergök, B. \& Yalçıner, K. (2011). Capital Structure Decisions of Manufacturing Firms in Developing Countries. Middle Eastern Finance and Economics, 12, 86-100.

Faccio, M. \& Masulis, R.W. (2005).The Choice of Payment Method in European Mergers and Acquisitions," Journal of Finance 60, 1345-1388. https://doi.org/10.1111/i.1540$\underline{6261.2005 .00764 . x}$

Flannery. M. \& Rangan, K. (2006). Partial Adjustment towards Target Capital Structures. Journal of Financial Economics 79,469-506. doi:10.1016/j.jfineco.2005.03.004

Frank, M.Z. \& Goyal, VK.(2003).Testing the Pecking Order Theory of Capital Structure. Journal of Financial Economics 67, 217-248. doi.org/10.1016/S0304-405X(02)00252-0

Frank, M. Z., \& Goyal, V. K. (2008). Trade-Off and Pecking Order Theories of Debt. Handbook of Empirical Corporate Finance. 2, 135-202. doi: 10.1016/B978-0-444-53265-7.50004-4

Frank, M. Z., \&Goyal, V. K. (2009). Capital Structure Decisions: Which Factors are Reliably Important? Financial Management, 38(1), 1-37. https://doi.org/10.1111/j.1755$\underline{053 X .2009 .01026 . x}$ 
Gajurel, D. P. (2006). Macroeconomic influences on corporate capital structure. Retrieved from SSRN: http://ssrn.com/abstract=899049 or http://dx.doi.org/10.2139/ssrn.899049

Gilson, S.C. (1997). Transactions Costs and Capital Structure Choice: Evidence from Financially Distressed Firms. Journal of Finance, 52, 161-196. https://doi.org/10.1111/i.15406261.1997.tb03812.x

Makro Analiz (2015, March). Growth, Inflation, Interest in Turkey and Other Fragile Five Economies. Retrieved from http://makroanaliz.blogspot.com.tr/2015/03/turkiyedebuyumeenflasyonfaiz-ve-diger.html

Hanousek, J. \&Shamshur, A. (2011). A stubborn persistence: Is the stability of leverage ratios determined by the stability of the economy? Journal of Corporate Finance, 17, 13601376.Retrieved from http://dx.doi.org/10.1016/j.jcorpfin.2011.07.004

Harris, M. \& Raviv, A. (1991). The Theory of Capital Structure, Journal of Finance, 46, 297356. doi: 10.1111/i.1540-6261.1991.tb03753.x

Hovakimian, A., Opler, T. \&Titman, S. (2001). The Debt-Equity Choice. Journal of Financial and Quantitative Analysis, 36, 1-24. doi: 10.2307/2676195

Huang, G., \& Song, F. M. (2006). The Determinants of Capital Structure: Evidence from China. China Economic Review, 17(1), 14-36. https://doi.org/10.1016/i.chieco.2005.02.007

Hull, R.M. (1999). Leverage Ratios, Industry Norms, and Stock Price Reaction: An Empirical Investigation of Stock-for-Debt Transactions. Financial Management, 28, 32-45. Doi: $\underline{10.2307 / 3666193}$

IMF (2015). Global Financial Stability Report October 2015, Vulnerabilities, Legacies, and Policy Challenges Risks Rotating to Emerging Markets). Retrieved from https://www.imf.org/external/pubs/ft/gfsr/2015/02/pdf/c3 v2.pdf

Jensen, M., \&Ruback, R. S. (1983). The market for corporate control: the scientific evidence. Journal of Financial Economics: 11, 5- 50. https://doi.org/10.1016/0304-405X(83)90004-1

Jensen, M.C. and W,H. Meckling, 1976, "Theory of the Firm: Managerial Behavior, Agency Costs and Ownership Structure," Journal of Financial Economics, 3, 305-360. https://doi.org/10.1016/0304-405X(76)90026-X

Jensen, M. (1986) Agency costs of free cash flow, corporate finance and takeovers. America Economic Review, 76, 323- 329. https://doi.org/10.2139/ssrn.99580

Jensen, M. (1988). Takeovers: their causes and consequences. Journal of Economic Perspectives, 2, 21- 48.

Kennedy, S. (2015). Fragile Five Down to Three as Fed Looms Over Emerging Markets. Retrieved from http://www.bloomberg.com/news/articles/2015-03-17/fragile-five-down-tothree-as-fed-looms-over-emerging-markets

Koksal, B. \&Orman, C. (2014). Determinants of Capital Structure: Evidence from a Major Developing Economy. Central Bank of the Republic of Turkey, Working Paper No. 14/26 https://link.springer.com/article/10.1007\%2Fs11187-014-9597-x

Miller, M. (1977). Debt and Taxes. Journal of Finance 32, 261-275. https://doi.org/10.1111/i.1540-6261.1977.tb03267.x

Modigliani, F. \& Miller, M. H. (1958).The Cost of Capital, Corporation Finance and the Theory of Investment. American Economic Review, 48(3), 261-297. 
Firm Specific and Macroeconomic Determinants of Capital Structure: Evidence from ...

Modigliani, F.\& Miller, M., H. (1963). Corporate Income Taxes and the Cost of Capital: A Correction. The American Economic Review, 53, 433-443. Retrieved from http://www.jstor.org/stable/1809167?origin=JSTOR-pdf

Myers, S. C., (1977). Determinants of corporate borrowing. Journal of Financial Economics, 5, 147-175 https://doi.org/10.1016/0304-405X(77)90015-0

Myers, S. C. (1984). The Capital Structure Puzzle. Journal of Finance, 39(3), 75-92. https://doi.org/10.2307/2327916

Myers, S. C., \& Majluf, N. S. (1984). Corporate Financing and Investment Decisions When Firms Have Information That Investors Do Not Have. Journal of Financial Economics, 13(2), 187-221. https://doi.org/10.1016/0304-405X(84)90023-0

Okuyan, H. A. \& Taşçı, H. M. (2010). Determinants of Capital Structure: A Study on Turkey's Largest 1,000 Industrial Enterprises. Journal of BRSA Banking and Financial Markets, 4(1), 105-120.

Retrieved from http://www.bddk.org.tr/WebSitesi/english/Reports/BRSA Journal/81575.makale\%20ing.pdf

Pinegar, J. M. \& Wilbricht, L., (1989): What managers think of capital structure theory: a survey. The Journal of the Financial Management Association, Winter, 82- 91. Retrieved from http://www.jstor.org/stable/3665800

Rajan, R. \& Zingales, L. (1995). What do we know about capital structure? Some Evidence from International Data. Journal of Finance, 50.1421-1460.

Ross, S. A. (1977). The determinants of financial structure: The incentive signaling approach. The Bell Journal of Economics and Management Science, 8, 232-240.

Roodman, D. (2006). How to do xtabond2: an introduction to "Difference" and "System" GMM in Stata. Center for Global Development. Working Paper Number 103 http://dx.doi.org/10.2139/ssrn.982943

Sett, K. \& Sarkhel, J. (2010). Macroeconomic variables, financial sector development and capital structure of Indian private corporate sector during the period 1981-2007. The IUP Journal of Applied Finance, 16(1), 40-56.

Stiglitz, J. E., (1972). Some Aspects of the Pure Theory of Corporate Finance: Bankruptcies and Take-Overs. Bell Journal of Economics, 3(2), 458-482.

Stohs, M. H., \&Mauer, D. C. (1996).The Determinants of Corporate Debt Maturity Structure. Journal of Business, 69(3), 279-312. http://dx.doi.org/10.1086/209692

Taggart, Jr. R. A. (1985). Secular Patterns in the Financing of US Corporations.Corporate Capital Structures in the United States. University of Chicago Press, Chicago. Retrieved from http://www.nber.org/chapters/c11417

Titman, S. (1984). The Effect of Capital Structure on a Firm's Liquidation Decision. Journal of Financial Economics, 13(1), 137-151. https://doi.org/10.1016/0304-405X(84)90035-7 